3. Смолінчук Л.С. Тестування як метод оцінювання навчальних досягнень студентів / Л.С. Смолінчук // Вісник Національного авіаційного університету. Серія: Педагогіка, Психологія: [зб. наук. праць] / [Електронний ресурс]. - 2010. - Режим доступу: http://jrnl.nau.edu.ua/index.php/VisnikPP/article/view/.

4. Булах I.С. Створюємо якісний тест: [навч. посіб.] / I.Є. Булах, М.Р. Мруга. - К. : Майстер-клас, 2006. - 160 с.

DOI https://doi.org/10.30525/978-9934-588-80-8-2.66

\title{
ОЦІНЮВАННЯ РІВНЯ ЗНАНЬ БАКАЛАВРІВ КОМП'ЮТЕРНИХ НАУК В ЗАКЛАДАХ ВИЩОЇ ОСВІТИ
}

\author{
Проскура С. Л. \\ старший викладач кафедри автоматизованих систем обробки \\ інформації і управління факультету \\ інформатики та обчислювальної техніки \\ НТУУ «Київський політехнічний інститут імені Ігоря Сікорського» \\ Кронда О. П. \\ ст.викладач кафедри Англійської мови гуманітарного спрясування № 3 \\ факультету лінгвістики \\ НТУУ «Київський політехнічний інститут імені Ігоря Сікорського» \\ Литвинова С. Г. \\ доктор педагогічних наук, \\ заступник директора з наукової роботи \\ Інститут інформачійних технологій $і$ засобів навчання \\ Національної академії педагогічних наук України \\ м. Київ, Украӥна
}

Стрімкий розвиток інформаційно-комунікаційних, WEB-орієнтованих та інноваційних технологій, що базуються на широкому використанні мережі Інтернет, змінюють принципи та підходи до навчання, зокрема бакалаврів комп'ютерних наук, у закладах вищої освіти. Відповідно виникає необхідність переосмислення та реструктуризації навчального процесу, оновлення змісту освітньої програми, форм, методів та засобів викладання [2, с. 611]. Важливим залишається питання підвищення якості професійної підготовки бакалаврів комп'ютерних наук, рівня їх професійної компетентності, яка б 250 
відповідала сучасним потребам IT-ринку, світовим вимогам і вимогам роботодавців [8, p. 11].

В свою чергу професійна компетентність визначається системою оцінювання рівня результатів навчальної діяльності студентів і має представляти собою цілісну структуру, що описує, вимірює, записує та передає результати досягнень студентів, підпорядковуючись чітко визначеним критеріям.

Підходи до оцінювання навчальних досягнень студентів закордонних та вітчизняних закладів вищої освіти висвітлені в роботах С.Г. Литвинової [4, 5], О.Г. Калініної [6], В.М. Кухаренка [7], Проскури С.Л. [10, 11], Турчина А.И. [12] та інших. Так, науковець О.Г. Калініна, дослідила, що міжнародна практика оцінювання рівня знань студентів увібрала в себе три основних підходи, які з'явилися незалежно один від одного, «спочатку в США (поведінковий підхід), потім у Великобританії (функціональний підхід) і в останню чергу у Франції й Німеччині (багатомірний підхід)» [6, с. 80].

Поведінковий підхід має за основу постановку критеріїв очікуваної поведінки студента у визначених ситуаціях, яка. при цьому, спрогнозована сукупністю таких процесів у навчанні, як постановка питання або проблеми, пошук відповіді або рішення студентом, та реакції викладача, яка спрямована на побудову рефлексивного поведінкового ефекту.Саме біхейвіористський (поведінковий) підхід, основною методикою якого $\epsilon$ орієнтація результатів навчання на відповідність рівню практичного застосування знань, став основою для формування поняття «компетенція», введеного американським ученим Р. Уайтом для опису тих особистісних характеристик, які «тісно пов'язані з ідеальним виконанням роботи й високою мотивацією» [6, с. 80].

Функціональний підхід ми спостерігаємо у дослідженнях університетів Великої Британії, де вчені підходять до визначення оцінювання рівня знань студентів, виділяючи наступні критерії: рівність горизонтальна (між предметами в різних закладах), рівність вертикальна ( в межах одного закладу), простота підходу, прозорість, послідовність, правомірність, цільова обгрунтованість, адміністративна ефективність, прийнятність для всіх зацікавлених сторін [1, с. 17].

Багатомірний підхід уособлює Німеччина, яка виступає лідером Європейської співдружності у багатьох питаннях, і прийняла Болонську систему кредитів для оцінювання рівня досягнень студентів з 2007 року, проте залишила за німецькими університетами «право вибору підготовки студентів як за класичним, так і за новим європейським варіантом підготовки бакалаврів і магістрів» [12, с. 183]. Варто зазначити, що український науковець В.М. Кухаренко, який присвятив багато 
досліджень темі оцінювання навчальних досягнень студентів, особливої уваги надає формуючому оцінюванню Німеччини [7, с. 89].

Поєднання американського поведінкового підходу до оцінювання рівня набутих студентами знань із структурно-функціональним багатомірним європейським підходом, а також розвиток поняття «компетенція», надало можливість для формування так званого «компетентнісного» підходу, в якому «знання, уміння і навички разом 3 поведінковими й мотиваційними аспектами ввійшли як складові елементи загальної кластерної структури компетенцій» [6, с. 81].

Саме компетентнісний підхід став основою авторської моделі формування професійної компетентності бакалаврів комп'ютерних наук на засадах використання WEB-орієнтованих технологій [10]. У даній моделі розглядається контрольно-оцінювальний блок, за допомогою якого можна визначити рівень компетентності студента не тільки в кінці курсу (іспит, заліки лабораторних робіт), а також протягом всього курсу навчальної дисципліни, використовуючи рівні таксономії Блума, які пов'язані з системою оцінювання ECTS та рейтинговим балом (див. Таблицю 1).

Критерії оцінювання практичного завдання прописуються для кожної теми за 6 рівнями складності. Кожне виконане практичне завдання відповідає своєму рівню 3 визначеною кількістю балів [10, p. 110].

Студент може вибирати і виконувати завдання відповідно до вибраного рівня його знань. Це спонукає його до саморозвитку, формування стилю навчання. На цьому етапі він завжди може підвищити свій професійний рівень, повернутися для відпрацювання більш складного завдання або закріпити складні моменти в розв'язанні завдань нижчих рівнів і т.п. [10, p. 110].

Таблиця 1

Таксономія Блума і бально-рейтингова система в оцінюванні досягнень студентів

\begin{tabular}{|c|c|c|c|c|}
\hline $\begin{array}{c}\text { Номер } \\
\text { рівня }\end{array}$ & $\begin{array}{c}\text { Назва рівня за } \\
\text { таксономісю } \\
\text { Блума }\end{array}$ & ECTS & Бали & $\begin{array}{c}\text { Роз'яснення } \\
\text { оцінок }\end{array}$ \\
\hline VI & Створення & A & $95-100$ & відмінно \\
\hline V & Оцінювання & В & $85-95$ & дуже добре \\
\hline IV & Аналіз & C & $75-85$ & добре \\
\hline III & Застосування & D & $70-75$ & дуже задовільно \\
\hline II & Усвідомлення & Dx & $65-70$ & задовільно \\
\hline I & Пригадування & E & $60-65$ & достатньо \\
\hline
\end{tabular}


Крім того, кожен рівень таксономії Блума, поділяється на такі підрозділи: виконання, захист, якість практичного завдання, звіт 3 практичного завдання, термін затримки виконання практичного завдання [11, p. 4].

Хочеться зауважити, що в системі оцінюваня рівня знань студентів велике значення мають результати виконання самостійної роботи, як невід'ємної складової частини навчально-виховного процесу, що має на меті забезпечити зворотній зв'язок «студент-викладач» і виявити на основі цього правильність ії організації. балів [3, p. 10].

Поєднання таксономії Блума і класичної бальної системи оцінювання знань студентів дасть можливість визначати компетентніть бакалаврів комп'ютерних наук як на проміжкових етапах навчання так і на завершальних. Вирішуючи завдання визначеного рівня, студент розуміє беспосередньо свій рівень знань.

\section{Література:}

1. Measuring and recording student achievement. Report of the Scoping Group chaired by Professor Robert Burgess. https://www.universitiesuk.ac.uk/ policy-and-analysis/reports/ Documents/ 2005/ measuring-and-recordingstudent-achievement.pdf

2. Proskura S.L., Lytvynova S.G. The approaches to Web-based education of computer science bachelors in higher education institutions. The 7th Workshop on Cloud Technologies in Education. December 18, 2019, Kryvyi Rih, Ukraine http://elibrary.kdpu.edu.ua/bitstream/123456789/ 3892/1/paper36.pdf

3. Proskura, S.L., Lytvynova, S.G.: Organization of Independent Studying of Future Bachelors in Computer Science within Higher Education Institutions of Ukraine. CEUR Workshop Proceedings 2104, 348-358 (2018) http://ceur-ws.org/Vol-2104/paper_160.pdf

4. Литвинова С. Г. Проектування хмаро орієнтованого навчального середовища загальноосвітнього навчального закладу : монографія. K. : Компринт, 2016. 354 с.

5. Литвинова С. Г. Компонентна модель хмаро орієнтованого навчального середовища загальноосвітнього навчального закладу. Нayковий вісник. Серія: Педагогіка. Соиіальна робота. Ужгород: УЖНУ, 2015. Випуск 35. С. 99-107.

6. Калініна О.Г.Система управління якістю освіти у вищих навчальних закладахСША.http://luguniv.edu.ua/wp-content/uploads/2015/ 12/d29.053.03_17.12.15_kalinina_dis.pdf

7. Кухаренко В. М . Теорія та практика змішаного навчання : монографія / С. М. Березенська, К. Л Бугайчук, Т.О. Олійник, 
О.В. Рибалко та ін.] ; за ред. В. М. Кухаренка. Харків : Міськдрук, НТУ XПI, 2016. $-284 \mathrm{c}$.

8. Проскура С.Л. Формування професійної компетентності майбутніх бакалаврів комп'ютерних наук. Фізико-математична освіта. 2019. Випуск 2(20). С. 138-146. https://fmo-journal. fizmatsspu.sumy.ua/publ/4-1-0-522 (2019).

9. Положення про рейтингову систему оцінювання результатів навчання НТУУ «Київський політехнічний інститут ім. І.Сікорського» https://kpi.ua/regulations-RSO

10. Проскура С.Л Модель формування професійної компетентності майбутніх бакалаврів комп'ютерних наук Фізико-математична освіта. 2019. Випуск 3(21). С. 104-112.

11.Проскура С.Л Таксономія блума в оцінюванні результатів освітньої діяльності студентів. Звітна наукова конферениія Інституту інформачійних технологій $i$ засобів навчання НАПН України. 2020, м. Київ, Україна.

12. Турчин.А.И. Система контролю й й оцінювання навчальних досягнень студентів ВНЗ Німеччини. Наукові записки. Серія: Педагогіка. -2010 - № 1 .

DOI https://doi.org/10.30525/978-9934-588-80-8-2.67

\title{
ДО ПРОБЛЕМИ ОЦНЮВАННЯ УСПІШНОСТІ ЗДОБУВАЧІВ ВИЩОЇ ОСВІТИ В УМОВАХ ДИСТАНЦІЙНОГО НАВЧАННЯ
}

\author{
Ремньова А. Г. \\ кандидат педагогічних наук, \\ стариий викладач кафедри теорії та історії педагогіки \\ Начіональний педагогічний університет імені М. П. Драгоманова \\ м. Київ, Україна
}

Дистанційна форма навчання сьогодні є доволі відомою і поширеною у світовій практиці, особливо у освітньому просторі закладів вищої освіти. Це пояснюється змінами, що сталися наприкінці 20-го на початку 21-го століття у соціо-культурному, політичному та соціально-економічному житті багатьох країн світу: переходом до інформаційного суспільства, підвищенням рівня інформаційних технологій, глобалізацією, зміною освітньої парадигми (від концепції «освіта на все життя» до концепції «освіта впродовж всього життя»). 